\title{
Effect of substituent groups in rhenium bipyridine complexes on photocatalytic $\mathrm{CO}_{2}$ reduction
}

\author{
Yoko Ono $^{1,2,{ }^{*} \text {, Jiro Nakamura }}{ }^{1}$, Masahiko Hayashi ${ }^{1,2}$, Kazue Ichino Takahashi, ${ }^{1,2}$ \\ ${ }^{1}$ NTT Energy and Environment Systems Laboratories, Kanagawa, Japan \\ ${ }^{2}$ Graduate School of Natural Science and Technology, Kanazawa University, Kanazawa, Ishikawa, Japan
}

Email address:

ono.yoko@lab.ntt.co.jp (Y. Ono)

\section{To cite this article:}

Yoko Ono, Jiro Nakamura, Masahiko Hayashi, Kazue Ichino Takahashi. Effect of Substituent Groups in Rhenium Bipyridine Complexes on Photocatalytic $\mathrm{CO}_{2}$ Reduction. American Journal of Applied Chemistry. Vol. 2, No. 5, 2014, pp. 74-79. doi: 10.11648/j.ajac.20140205.12

\begin{abstract}
We synthesized four different rhenium complexes, $\mathrm{Re}($ bpy- $\mathrm{R})(\mathrm{CO}){ }_{3} \mathrm{Cl}\left(\mathrm{bpy}=2,2^{\prime}\right.$-bipyridine and $\mathrm{R}=\mathrm{H}, \mathrm{CH}_{3}$, $\mathrm{COOH}$, or $\mathrm{CN}$ ), as photocatalysts that selectively reduce $\mathrm{CO}_{2}$ to $\mathrm{CO}$ and investigated the effect of substituent groups (Rs) on the absorption and photocatalystic properties for $\mathrm{CO}_{2}$ reduction under $365-\mathrm{nm}$ light irradiation. The $\mathrm{Re}(\mathrm{bpy}-\mathrm{R})(\mathrm{CO}){ }_{3} \mathrm{Cl}(\mathrm{R}=\mathrm{H}$ or $\mathrm{CH}_{3}$ or $\mathrm{COOH}$ ) reduced $\mathrm{CO}_{2}$ to $\mathrm{CO}$ in $\mathrm{CO}_{2}$-saturated DMF-triethanolamine solution, which was irradiated with 365-nm light. The amount of $\mathrm{CO}$ produced by $\mathrm{CO}_{2}$ reduction differed, depending on the introduced Rs in the bipyridine moiety. We found that the ability of $\mathrm{Re}($ bpy- $\mathrm{R})(\mathrm{CO})_{3} \mathrm{Cl}\left(\mathrm{R}=\mathrm{H}\right.$ or $\mathrm{CH}_{3}$ or $\left.\mathrm{COOH}\right)$ to produce $\mathrm{CO}$ has a linear relationship to molar absorption coefficients of rhenium complexes at the irradiated light wavelength. Introduction of the $\mathrm{COOH}$ group, which has the highest molar absorption coefficient among four rhenium complexes, enhanced $\mathrm{CO}_{2}$-to- $\mathrm{CO}$ reduction capacity $(6.59 \mathrm{~mol} / \mathrm{cat}-\mathrm{mol} \cdot 2 \mathrm{~h})$ five times that of $\mathrm{Re}(\mathrm{bpy}-\mathrm{H})(\mathrm{CO})_{3} \mathrm{Cl}$ with no $\mathrm{R}$.
\end{abstract}

Keywords: $\mathrm{CO}_{2}$ Reduction, Photocatalyst, Rhenium Bipyridine Complex

\section{Introduction}

Recently, much attention has been focused on photochemical $\mathrm{CO}_{2}$ reduction using photocatalysts because it can both reduce $\mathrm{CO}_{2}$ and produce chemicals such as $\mathrm{CO}$, $\mathrm{CH}_{3} \mathrm{OH}$, and $\mathrm{CH}_{4}$ as fuels [1]. The rhenium bipyridine complex $\operatorname{Re}($ bpy $)(\mathrm{CO})_{3} \mathrm{Cl}$ (bpy $=2,2^{\prime}$-bipyridine) has been reported to act as a photocatalyst that photochemically reduces $\mathrm{CO}_{2}$ to $\mathrm{CO}$ and/or $\mathrm{COOH}$ in the presence of electron donors, such as triethanolamine (TEOA), under UV light irradiation [2-18] (Scheme 1). Many researchers have focused on increasing the reaction efficiency of the photoreduction of $\mathrm{CO}_{2}$ to $\mathrm{CO}$ by substituting $\mathrm{Cl}$ with a certain ligand. A number of studies on $\operatorname{Re}($ bpy $)(\mathrm{CO})_{3} \mathrm{~L}$ compounds $(\mathrm{L}=\mathrm{Br}[3,12]$, $\mathrm{OClO}_{3}[3], \mathrm{PPh}_{3}[4],\left\{\mathrm{P}(\mathrm{OEt})_{3}\right\}$ [5], 4-Xpy $(\mathrm{Xpy}=$ pyridine derivatives) [6], and $\mathrm{SCN}$ [12] ) have demonstrated that longer lifetime of the triplet state of a metal to ligand charge transfer $\left({ }^{3} \mathrm{MLCT}\right)$ excited state enhances the rate constant for the formation of one-electron reduced intermediates, which enhances reaction efficiency. We have reported $\mathrm{Re}$ (bathophenanthroline) $(\mathrm{CO})_{3} \mathrm{Cl} \quad(\mathrm{Re}(\mathrm{btp}))$ as a $\mathrm{CO}_{2}$ reduction photocatalyst with six times higher efficiency than that of $\mathrm{Re}(\mathrm{bpy})(\mathrm{CO})_{3} \mathrm{Cl}$ [20]. We also found that $\mathrm{CO}$ was found to be produced by both $\mathrm{Re}(\mathrm{btp})(\mathrm{CO})_{3} \mathrm{Cl}$ degradation and $\mathrm{CO}_{2}$ reduction and established an analytical method to determine the net amount of $\mathrm{CO}$ produced by $\mathrm{CO}_{2}$ reduction by taking $\mathrm{Re}(\mathrm{btp})(\mathrm{CO})_{3} \mathrm{Cl}$ degradation into consideration. On the other hand, as for substituent groups (Rs) introduced to bipyridine moiety, such as $\mathrm{CH}_{3}, \mathrm{OCH}_{3}, \mathrm{CF}_{3}, \mathrm{CH}_{3}, \mathrm{C}_{6} \mathrm{~F}_{13}\left(\mathrm{CH}_{2}\right)_{3}$, and $\mathrm{C}_{8} \mathrm{~F}_{17}\left(\mathrm{CH}_{2}\right)_{3}$, have been reported $[6,8,9,10,15,19]$. The electron-withdrawing $\left(\mathrm{CH}_{2}\right)_{3}$ group of $\mathrm{C}_{6} \mathrm{~F}_{13}\left(\mathrm{CH}_{2}\right)_{3}$ and $\mathrm{C}_{8} \mathrm{~F}_{17}\left(\mathrm{CH}_{2}\right)_{3}$ greatly enhanced the lifetime of the ${ }^{3} \mathrm{MLCT}$ state, resulting to high efficiency of $\mathrm{CO}$ production. Thus, Rs are one of factors that affect $\mathrm{CO}_{2}$ reduction properties. However, a correlation between $\mathrm{Rs}$ and $\mathrm{CO}$ production is still worth investigating to enhance $\mathrm{CO}_{2}$ reduction efficiency.

The object of the present study was mainly to clarify the effect of the $\mathrm{R}$ of bipyridine moieties on $\mathrm{CO}$ production. We synthesized four kinds of $\mathrm{Re}(\mathrm{bpy})(\mathrm{CO})_{3} \mathrm{Cl} \quad(\mathrm{Re}(\mathrm{bpy}-\mathrm{R}) ; \mathrm{R}=$ $\mathrm{H}, \mathrm{CH}_{3}, \mathrm{COOH}$, or $\mathrm{CN}$ ) as photocatalysts (Fig. 1). The $\mathrm{CH}_{3}$ was selected as an electron-donating group, and $\mathrm{COOH}$ or $\mathrm{CN}$ was selected as an electron-withdrawing group, with the expectation that the $\mathrm{R}$ affects the electronic state of the bipyridine moiety and that each $\operatorname{Re}($ bpy-R) exhibits different photocatalytic performance. We revealed the correlation between the ultraviolet-visible spectroscopy (UV-Vis) absorption properties and $\mathrm{CO}_{2}$ reduction properties of those 
compounds. The $\mathrm{CO}$ production efficiency was greatly enhanced by the novel Re(bpy-COOH).

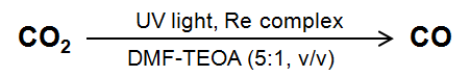

Scheme 1. Photocatalytic $\mathrm{CO}_{2}$ reduction to $\mathrm{CO}$ by Re complex.

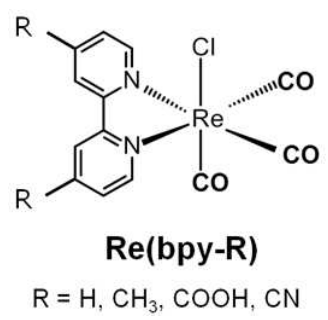

Figure 1. Chemical structure of Re(bpy-R) complexes.

\section{Experimental}

\subsection{Instrumentations}

The UV-Vis absorption spectral measurements were performed with a Shimadzu UV-2200 spectrophotometer. The infrared (IR) spectra were recorded using a Perkin Elmer System 2000 FT-IR spectrometer. Elemental analysis was performed using a VARIO EL III analyzer. Proton-nuclear magnetic resonance (NMR) spectra were measured using a JEOL ECA-400 system. The atmospheric pressure chemical ionization (APCI) mass spectra and electrospray ionization (ESI) mass spectra were measured using a Waters LCT Premier XE instrument in the negative-ion mode. The $\mathrm{CO}$ amount produced by $\mathrm{CO}_{2}$ photoreduction was analyzed using a Shimadzu GCMS-QP2010 Plus instrument equipped with an Rt-Molsieve 5A column $(L=30 \mathrm{~m}, \phi=0.32 \mathrm{~mm}, d=30$ $\mu \mathrm{m})$.

\subsection{Materials}

All solvents were of high purity and used as received from Kanto Chemical Co. Rhenium pentacarbonyl chloride $\left(\mathrm{Re}(\mathrm{CO})_{5} \mathrm{Cl}\right)$ and 2,2'-bipyridine (bpy) were purchased from Aldrich Chemical Co. and Kanto Chemical Co and the bpy derivatives were purchased from Tokyo Chemical Industry Co.. All reagents were used without further purification. The $\mathrm{Re}\left(\right.$ bpy-R) was synthesized using $\mathrm{Re}(\mathrm{CO})_{5} \mathrm{Cl}$ and bpy or bpy derivatives as precursors, according to a previous work [13]. The general synthetic procedure is shown in Scheme 2. The detail procedure is described in the following paragraph.

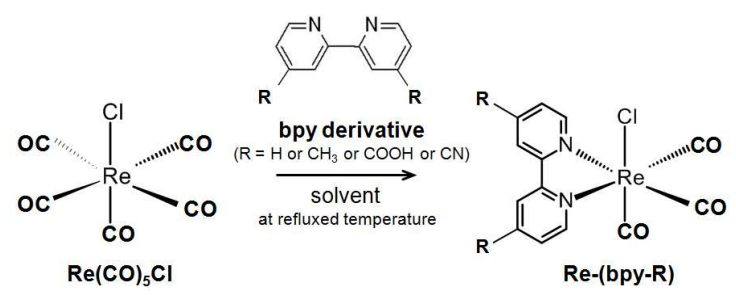

Scheme 2. Chemical structure of Re(bpy-R) complexes.

\subsubsection{Synthesis of $\operatorname{Re}(\mathrm{bpy}-\mathrm{H})$}

A solution of 2,2'-bipyridine ( $117 \mathrm{mg}, 0.75 \mathrm{mmol}$ ) in $20 \mathrm{~mL}$ of toluene was added to a solution of $\operatorname{Re}(\mathrm{CO})_{5} \mathrm{Cl}(271 \mathrm{mg}$, $0.75 \mathrm{mmol}$ ) in $130 \mathrm{~mL}$ of toluene at $110^{\circ} \mathrm{C}$. The mixture was kept at $110^{\circ} \mathrm{C}$ and stirred vigorously for $3 \mathrm{~h}$ until the solution became a brown-orange color. The solvent was then evaporated in vacuum, and the starting materials were removed by column chromatography $(\mathrm{H}=300 \mathrm{~mm}, \phi=25$ $\mathrm{mm}$ ) on silica using ethyl acetate as an eluent. Then, the brown-orange compound was obtained using methanol as an eluent. After that, the solvent was removed, and the solid product was recrystallized from acetone-hexane. Yield: 78.0 mg (22.5\%) Anal. Calcd for $\mathrm{C}_{13} \mathrm{H}_{8} \mathrm{ClN}_{2} \mathrm{O}_{3} \mathrm{Re}: \mathrm{C}, 33.8 ; \mathrm{H}, 1.7$; $\mathrm{N}, 6.1 ; \mathrm{O}, 10.5$. Found: C, 33.6; H, 1.9; N, 5.9; O, 10.6. ${ }^{1} \mathrm{H}$ NMR (400 MHz, DMSO- $\left.d_{6}\right): \delta=9.02(\mathrm{dd}, 2 \mathrm{H}, J=0.9 \mathrm{~Hz}$, $5.5 \mathrm{~Hz}$, bpy $\left.H^{6}, H^{6^{\prime}}\right), 8.77\left(\mathrm{~d}, 2 \mathrm{H}, J=8.2 \mathrm{~Hz}\right.$, bpy $\left.H^{3}, H^{3^{\prime}}\right)$, 8.35 (dt, $2 \mathrm{H}, J=1.2 \mathrm{~Hz}, 7.9 \mathrm{~Hz}$, bpy $H^{4}, H^{4^{\prime}}$ ), 7.77 (ddd, 2H, $J=1.2 \mathrm{~Hz}, 5.5 \mathrm{~Hz}, 7.6 \mathrm{~Hz}$, bpy $\left.H^{5}, H^{5^{\prime}}\right)$. FT-IR $\left(\mathrm{v}_{\mathrm{CO}} / \mathrm{cm}^{-1}\right)$ : 2024, 1921, 1899 in $\mathrm{CH}_{2} \mathrm{Cl}_{2}$. UV-Vis $\left(\varepsilon_{\max } / \mathrm{nm}\left(\varepsilon / \mathrm{M}^{-1} \mathrm{~cm}^{-1}\right)\right.$ : 290 (12167) in DMF-TEOA $(5: 1, \mathrm{v} / \mathrm{v})$. APCI-MS $(\mathrm{m} / \mathrm{z})$ : $462.0\left(\mathrm{M}^{-}\right)$in $\mathrm{MeOH}$.

\subsubsection{Synthesis of $\mathrm{Re}\left(\mathrm{bpy}-\mathrm{CH}_{3}\right)$}

A solution of 4,4'-dimethyl-2,2'-dipyridyl (138 mg, 0.75 $\mathrm{mmol})$ in $50 \mathrm{~mL}$ of toluene was added to a solution of $\mathrm{Re}(\mathrm{CO})_{5} \mathrm{Cl}(271 \mathrm{mg}, 0.75 \mathrm{mmol})$ in $100 \mathrm{~mL}$ of toluene at $110{ }^{\circ} \mathrm{C}$. The mixture was kept at $110^{\circ} \mathrm{C}$ and stirred vigorously for $4 \mathrm{~h}$ until the solution became a brown-orange color. The solvent was then evaporated in vacuum, and the brown-orange compound was isolated by column chromatography $(\mathrm{H}=300$ $\mathrm{mm}, \phi=25 \mathrm{~mm}$ ) on silica using ethyl acetate as an eluent. After the solvent had been removed, the solid product was recrystallized from acetone-hexane. Yield: $260.0 \mathrm{mg}(70.3 \%)$ Anal. Calcd for $\mathrm{C}_{15} \mathrm{H}_{12} \mathrm{ClN}_{2} \mathrm{O}_{3} \mathrm{Re}: \mathrm{C}, 36.8 ; \mathrm{H}, 2.5 ; \mathrm{N}, 5.7 ; \mathrm{O}$, 9.8. Found: C, 36.8; H, 2.5; N, 5.7; O, 9.8. ${ }^{1} \mathrm{H}$ NMR (400 $\left.\mathrm{MHz}, \mathrm{DMSO}-d_{6}\right): \delta=8.83\left(\mathrm{~d}, 2 \mathrm{H}, J=5.8 \mathrm{~Hz}\right.$, bpy $\left.H^{6}, H^{6^{\prime}}\right)$, $8.62\left(\mathrm{~s}, 2 \mathrm{H}\right.$, bpy $\left.H^{3}, H^{3^{\prime}}\right), 7.58(\mathrm{dd}, 2 \mathrm{H}, J=0.9 \mathrm{~Hz}, 5.8 \mathrm{~Hz}$, bpy $\left.H^{5}, H^{5^{\prime}}\right), 2.55\left(\mathrm{~s}, 6 \mathrm{H}\right.$, bpy $\left.\mathrm{CH}_{3}\right)$. FT-IR $\left(\mathrm{v}_{\mathrm{CO}} / \mathrm{cm}^{-1}\right): 2022$, 1917, 1895 in $\mathrm{CH}_{2} \mathrm{Cl}_{2}$. UV-Vis $\left(\varepsilon_{\max } / \mathrm{nm}\left(\varepsilon / \mathrm{M}^{-1} \mathrm{~cm}^{-1}\right): 290\right.$ (12167) in DMF-TEOA $(5: 1, \mathrm{v} / \mathrm{v})$. APCI-MS $(\mathrm{m} / \mathrm{z}): 490.0$ $\left(\mathrm{M}^{-}\right)$in $\mathrm{MeOH}$.

\subsubsection{Synthesis of $\operatorname{Re}(\mathrm{bpy}-\mathrm{COOH})$}

A solution of 4,4'-dicarboxy-2,2'-dipyridyl (224 mg, 1.00 $\mathrm{mmol})$ in $100 \mathrm{~mL}$ of ethanol was added to a solution of $\mathrm{Re}(\mathrm{CO})_{5} \mathrm{Cl}(361 \mathrm{mg}, 1.00 \mathrm{mmol})$ in $100 \mathrm{~mL}$ of ethanol at $75{ }^{\circ} \mathrm{C}$. The mixture was kept at $75{ }^{\circ} \mathrm{C}$ and stirred vigorously for $5 \mathrm{~h}$ until the solution became a brown-orange color. The solvent was then evaporated in vacuum. The solid product was recrystallized from acetone-hexane. Yield: $220.6 \mathrm{mg}$ (40.1\%) Anal. Calcd for $\mathrm{C}_{15} \mathrm{H}_{8} \mathrm{ClN}_{2} \mathrm{O}_{7}$ Re: $\mathrm{C}, 33.8 ; \mathrm{H}, 1.7 ; \mathrm{N}, 6.1$; O, 10.4. Found: C, 33.6; H, 2.8; N, 4.3; O, 10.5. ${ }^{1} \mathrm{H}$ NMR (400 $\left.\mathrm{MHz}, \mathrm{DMSO}-d_{6}\right): \delta=14.4(\mathrm{~s}, 1 \mathrm{H}, \mathrm{bpy} \mathrm{COO} H), 9.21(\mathrm{~d}, 2 \mathrm{H}$, $J=5.8 \mathrm{~Hz}$, bpy $\left.H^{6}, H^{6^{\prime}}\right), 9.15\left(\mathrm{~d}, 2 \mathrm{H}, J=0.9 \mathrm{~Hz}\right.$, bpy $\left.H^{3}, H^{3^{\prime}}\right)$, $8.31\left(\mathrm{dd}, 2 \mathrm{H}, J=1.5 \mathrm{~Hz}, 5.8 \mathrm{~Hz}\right.$, bpy $\left.H^{5}, H^{5^{\prime}}\right)$. FT-IR ( $v_{\mathrm{CO}}$ $\left./ \mathrm{cm}^{-1}\right)$ : N.D. in $\mathrm{CH}_{2} \mathrm{Cl}_{2}$. UV-Vis $\left(\varepsilon_{\max } / \mathrm{nm}\left(\varepsilon / \mathrm{M}^{-1} \mathrm{~cm}^{-1}\right): 305\right.$ (14211) in DMF-TEOA $(5: 1, \mathrm{v} / \mathrm{v})$. ESI-MS $(\mathrm{m} / \mathrm{z}): 505.0$ $\left([\mathrm{M}-\mathrm{COOH}]^{-}\right), 548.9\left(\mathrm{M}^{-}\right)$in $\mathrm{MeOH}$. 


\subsubsection{Synthesis of Re(bpy-CN)}

A solution of 4,4'-dicyano-2,2'-dipyridyl (154 mg, 0.75 $\mathrm{mmol}$ ) in $50 \mathrm{~mL}$ of toluene was added to a solution of $\operatorname{Re}(\mathrm{CO})_{5} \mathrm{Cl}(271 \mathrm{mg}, 0.75 \mathrm{mmol})$ in $100 \mathrm{~mL}$ of toluene at $110{ }^{\circ} \mathrm{C}$. The mixture was kept at $110^{\circ} \mathrm{C}$ and stirred vigorously for $3 \mathrm{~h}$ until the solution became a brown-orange color. The solvent was then filtered and the solid product was recrystallized from acetone-hexane. Yield: $231.1 \mathrm{mg}(60.3 \%)$ Anal. Calcd for $\mathrm{C}_{15} \mathrm{H}_{6} \mathrm{~N}_{4} \mathrm{O}_{3}$ ClRe: C, 35.2; H, 1.2; N, 11.0; O, 9.38. Found: $\mathrm{C}, 35.3 ; \mathrm{H}, 1.31 ; \mathrm{N}, 10.8 ; \mathrm{O}, 10.2 .{ }^{1} \mathrm{H}$ NMR $\left(400 \mathrm{MHz}, \mathrm{DMSO}-d_{6}\right): \delta=9.39\left(\mathrm{~d}, 2 \mathrm{H}, J=0.9 \mathrm{~Hz}\right.$, bpy $H^{3}$, $\left.H^{3}\right), 9.29\left(\mathrm{dd}, 2 \mathrm{H}, J=0.6 \mathrm{~Hz}, 5.8 \mathrm{~Hz}\right.$, bpy $\left.H^{6}, H^{6^{\prime}}\right), 8.23(\mathrm{dd}$, $2 \mathrm{H}, J=1.5 \mathrm{~Hz}, 5.8 \mathrm{~Hz}$, bpy $\left.H^{5}, H^{5^{\prime}}\right)$. FT-IR $\left(v_{\mathrm{CO}} / \mathrm{cm}^{-1}\right): 2028$, 1935, 1915 in $\mathrm{CH}_{2} \mathrm{Cl}_{2}$. UV-Vis $\left(\varepsilon_{\max } / \mathrm{nm}\left(\varepsilon / \mathrm{M}^{-1} \mathrm{~cm}^{-1}\right): 319\right.$ $(16948)$ in DMF-TEOA $(5: 1, \mathrm{v} / \mathrm{v})$. APCI-MS $(\mathrm{m} / \mathrm{z}): 512.0$ $\left(\mathrm{M}^{-}\right), 511.0\left([\mathrm{M}-\mathrm{H}]^{-}\right)$in $\mathrm{CH}_{3} \mathrm{CN}$.

\subsection{Photochemical $\mathrm{CO}_{2}$ Reduction}

Photochemical $\mathrm{CO}_{2}$ reduction was done according to a conventional method [11]. The detail of experimental set-up was described in the previous paper [20]. The photocatalytic reaction was tested in a quartz cell $($ vol. $=5 \mathrm{~mL})$ containing $2.0 \mathrm{~mL}$ of Re(bpy-R) DMF-triethanolamine (TEOA) $(5: 1, \mathrm{v} / \mathrm{v})$ solution (conc. $=0.05 \mathrm{mM}$ ) that was stirred at room temperature during light irradiation. The solution was bubbled with $\mathrm{CO}_{2}$ for 2 min with a flow rate of $200 \mathrm{~mL} / \mathrm{min}$ and sealed with a silicon-teflon septum. As a light source, a mercury lamp $\left(\lambda=365 \mathrm{~nm}, \mathrm{I}=614 \mu \mathrm{W} / \mathrm{cm}^{2}\right)$ was used for the photocatalytic reaction of $\mathrm{CO}_{2}$. The reaction products were analyzed using gas chromatography-mass spectrometry at an arbitrary time. Moreover, during irradiation, the amount of residual Re complexes was determined by measuring the absorption maximum at the $\pi-\pi^{*}$ transition peak for each Re(bpy-R) [20].

\section{Results and Discussion}

\subsection{Absorption Properties}

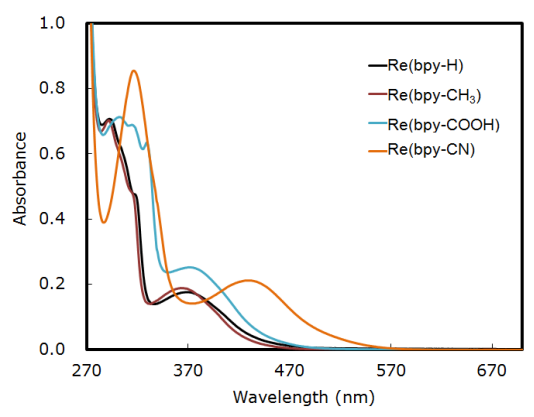

Figure 2. Steady-state absorption spectra of Re(bpy-R) complexes in DMF-TEOA $(5: 1, v / v)$ solution (conc. $=0.05 \mathrm{mM})$.

Figure 2 shows the steady-state UV-Vis absorption spectra of Re(bpy-R) complexes in DMF-TEOA solution. The spectral shapes were similar to each other and had characteristics in common with Re complexes that contain bpy derivatives as a ligand [14]. Absorption bands at around 300 to $350 \mathrm{~nm}$ were assigned to the $\pi-\pi^{*}$ transition of the bpy moiety and those around 350 to $400 \mathrm{~nm}$ were assigned to the MLCT transition. The wavelength of the absorption maximum and each molar adsorption coefficient $(\varepsilon)$ differed depending on the kinds of R. The $\varepsilon$ of the $\pi-\pi^{*}$ absorption maximum for $\operatorname{Re}($ bpy-COOH) was almost the same as that for $\operatorname{Re}(b p y-H)$ and $\operatorname{Re}\left(b p y-\mathrm{CH}_{3}\right)$. For $\operatorname{Re}\left(\right.$ bpy-CN), $\varepsilon$ of both $\pi-\pi^{*}$ and MLCT absorption maxima were increased by about 1.2 times those for the other Re complexes, and the wavelength of the absorption maximum of the MLCT transition exhibited a long-wavelength shift of 60 $\mathrm{nm}$. This wavelength shift was due to a decrease in the lowest unoccupied molecular orbital (LUMO) energy by the electron-withdrawing effect of the $\mathrm{CN}$ group. These results indicated that introducing electron-withdrawing groups into bpy moiety affected the electron-transition probability and highest occupied molecular orbital (HOMO)-LUMO energy levels.
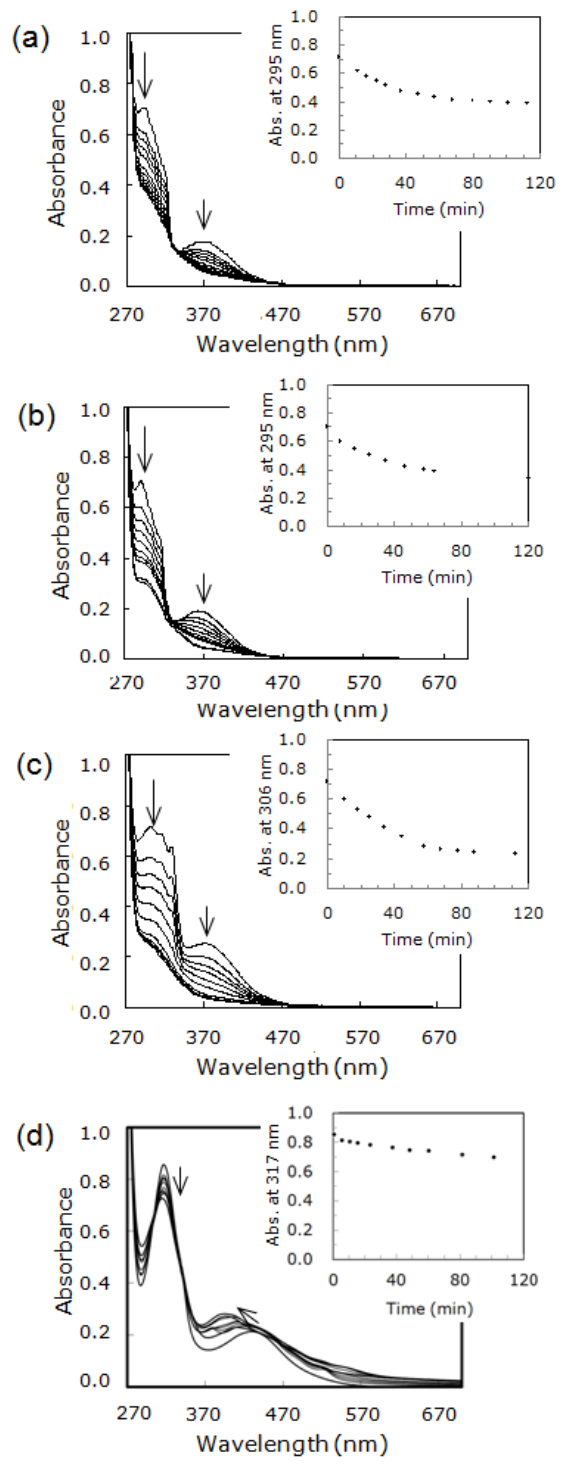

Figure 3. Ex-situ UV-Vis absorption spectral changes for (a) Re(bpy-H), (b) $\operatorname{Re}\left(b p y-\mathrm{CH}_{3}\right)$, (c) $\operatorname{Re}(b p y-C O O H)$, and (d) Re(bpy-CN) in DMF-TEOA (5:1, $v / v)$ solution during 365-nm light irradiation for $2 \mathrm{~h}$. Inset is absorbance at wavelength of $\pi-\pi^{*}$ absorption maximum vs. irradiation time plots. 
Figure 3 shows ex-situ UV-Vis absorption spectral changes for $\operatorname{Re}(b p y-R)$ in DMF-TEOA $(5: 1, \mathrm{v} / \mathrm{v})$ solution during 365-nm light irradiation for $2 \mathrm{~h}$. For $\mathrm{R}=\mathrm{H}$ (Fig. 3 (a)), $\mathrm{CH}_{3}$ (Fig. 3 (b)), and $\mathrm{COOH}$ (Fig. 3 (c)), the absorbance intensity of both $\pi-\pi^{*}$ and MLCT decreased by irradiation with 365 -nm-light for $2 \mathrm{~h}$. After removal of the light source, each $\operatorname{Re}($ bpy-R) solution retained its absorption intensity for more than $24 \mathrm{~h}$. This result suggested that light irradiation induced irreversible degradation of $\operatorname{Re}(b p y-R)$. On the other hand, for $\mathrm{R}=\mathrm{CN}$ (Fig. 3 (d)), while the absorption intensity slightly changed, significant intensity decrease was not observed. The inset in Fig. 3 shows absorbance change at the wavelength of the $\pi-\pi^{*}$ absorption maximum. This absorbance decrease was due to degradation of $\operatorname{Re}($ bpy-R) by light irradiation. Therefore, the degradation rate constant $\left(k_{d}\right)$ was determined for each $\mathrm{Re}\left(\right.$ bpy-R) $\left(\mathrm{R}=\mathrm{H}, \mathrm{CH}_{3}, \mathrm{COOH}\right)$ by applying the method proposed in our previous work [20]. Table 1 summarizes the $k_{d}$ values for $\operatorname{Re}($ bpy-R) together with the $\mathrm{C} 1$ s group shift $\left(\Delta E_{g r}\right)$ of each $\mathrm{R}$ [21]. The C1s group shift is the energy shift affected by an R bounded to carbon. Each Re(bpy-R) shows a different $k_{d}$ value depending on the $\mathrm{R}$. It was also found that the higher the $\mathrm{C} 1 \mathrm{~s}$ group shift $\left(\Delta E_{g r}\right)$, the larger the $k_{d}$ value. The results indicate that the electronic state of the R may affect the $k_{d}$ of Re(bpy-R) under 365-nm light irradiation. It was indicated that the Rs of the low $\mathrm{C} 1 \mathrm{~s}$ group shift $\left(\Delta E_{g r}\right)$ may be potential candidates to prevent degradation of Re(bpy-R).

Table 1. Degradation rate constants for Re(bpy-R) under 365-nm light irradiation.

\begin{tabular}{lll}
\hline $\operatorname{Re}($ bpy-R) & $\boldsymbol{k}_{\boldsymbol{d}}\left(\mathbf{s}^{-\mathbf{1}}\right)$ & $\boldsymbol{\Delta} \boldsymbol{E}_{\boldsymbol{g r}}(\mathbf{e V})[21]$ \\
\hline $\mathrm{R}=\mathrm{H}$ & $5.35 \times 10^{-4}$ & 0.01 \\
$\mathrm{R}=\mathrm{CH}_{3}$ & $3.41 \times 10-4$ & -0.32 \\
$\mathrm{R}=\mathrm{COOH}$ & $3.87 \times 10-4$ & -0.15 \\
\hline
\end{tabular}

\subsection{Photocatalytic Properties}

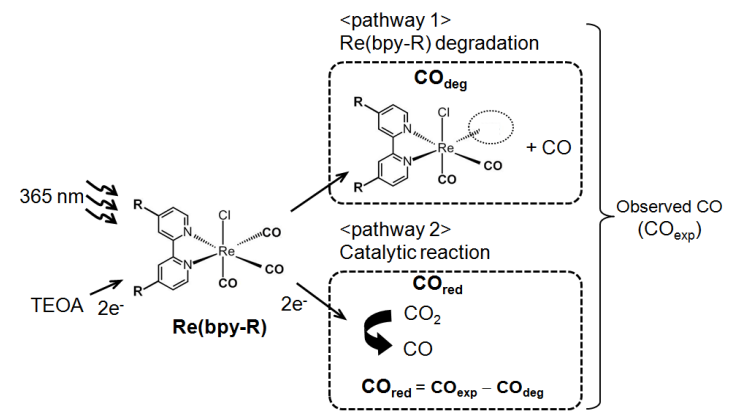

Scheme 3. CO formation pathway in $\mathrm{CO}_{2}$ reduction by $\mathrm{Re}$ (bpy- $\mathrm{R}$ ).

The $\mathrm{CO}$ was produced when $\mathrm{Re}(\mathrm{bpy}-\mathrm{R})\left(\mathrm{R}=\mathrm{H}\right.$ or $\mathrm{CH}_{3}$ or $\mathrm{COOH})$ in the $\mathrm{CO}_{2}$-saturated DMF-TEOA solution was irradiated with $365-\mathrm{nm}$ light. The $\mathrm{CO}$ formation increased depending on the irradiation time then reached the saturation point at about $120 \mathrm{~min}$. When using $\operatorname{Re}(\mathrm{bpy}-\mathrm{CN})$, on the other hand, $\mathrm{CO}$ formation was not observed. Since the observed $\mathrm{CO}$ might include not only $\mathrm{CO}$ from $\mathrm{CO}_{2}$ reduction (pathway 2 in Scheme 3) but also $\mathrm{CO}$ from the degradation of $\operatorname{Re}($ bpy-R) (pathway 1 in Scheme 3 ), we took the degradation process of $\operatorname{Re}(b p y-R)$ into consideration. Therefore, the net amount of $\mathrm{CO}$ production by $\mathrm{CO}_{2}$ reduction was determined by subtracting the $\mathrm{CO}$ produced by Re(bpy-R) degradation (pathway 2 in Scheme 3) from the $\mathrm{CO}$ observed in the reaction cell, employing a kinetic study [20].

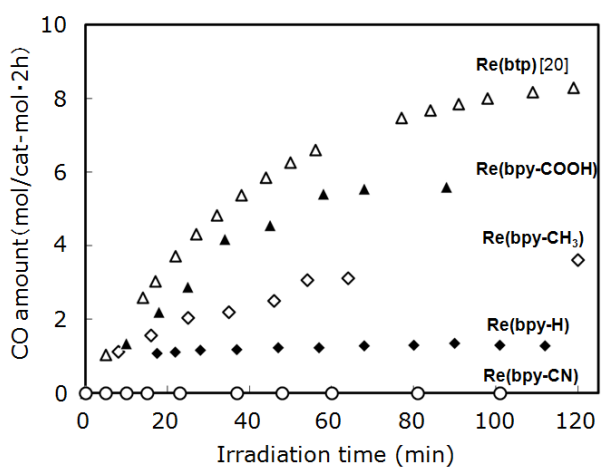

Figure 4. CO amount vs. irradiation time plots. ( $\mathbf{\Delta}: \operatorname{Re}(b p y-C O O H)$, \$: $\left.\operatorname{Re}\left(b p y-\mathrm{CH}_{3}\right), \bullet: \operatorname{Re}(b p y), o: \operatorname{Re}(b p y-C N), \Delta: \operatorname{Re}(b t p)[20]\right)$.

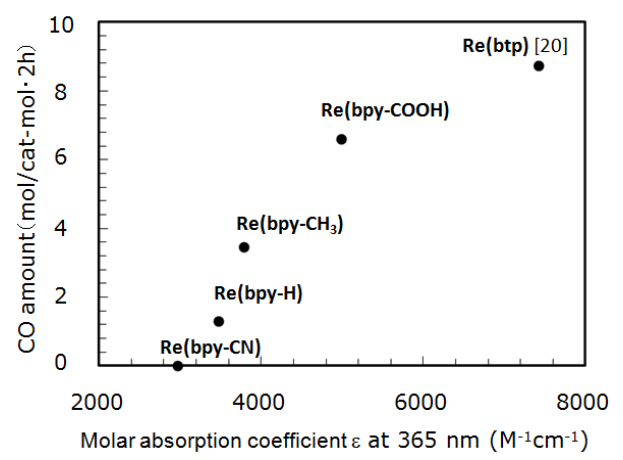

Figure 5. CO amount vs. molar absorption coefficients (E) at 365-nm plots for each Re(bpy-R). Results for Re(btp)in our previous study [20] are also plotted.

Figure 4 shows the net amount of $\mathrm{CO}$ production by $\operatorname{Re}($ bpy-R) at an arbitrary irradiation time. The results for $\mathrm{Re}$ (btp) [20] are plotted together. The total amount of $\mathrm{CO}$ production was $6.59,3.44,1.28$, and $0 \mathrm{~mol} / \mathrm{cat}-\mathrm{mol} \cdot 2 \mathrm{~h}$ for $\mathrm{R}$ $=\mathrm{COOH}, \mathrm{CH}_{3}, \mathrm{H}$, and $\mathrm{CN}$, respectively. The $\mathrm{R}, \mathrm{COOH}$ or $\mathrm{CH}_{3}$, increased $\mathrm{CO}$ production by about five or three times compared to $\mathrm{R}=\mathrm{H}$, respectively. To investigate the difference in $\mathrm{CO}$ production for each $\mathrm{Re}(\mathrm{bpy}-\mathrm{R})$, we discuss the relationship between the absorption and photocatalytic properties. Figure 5 shows the correlation between $\mathrm{CO}$ amount and molar absorption coefficients at 365-nm plots for each $\operatorname{Re}(b p y-R)$ and $\operatorname{Re}(b t p)$. In the range of 3000 to 5000 $\mathrm{M}^{-1} \mathrm{~cm}^{-1}$, the plots indicate that the ability of Re complexes to produce $\mathrm{CO}$ has a linear relationship to those molar absorption coefficients. The Re complexes with a higher molar absorption coefficient exhibit higher $\mathrm{CO}$ production ability. This correlation is also in agreement with the results for $\mathrm{Re}(\mathrm{btp})(\mathrm{CO})_{3} \mathrm{Cl}$, which has ability of $8.73 \mathrm{~mol} / \mathrm{cat}-\mathrm{mol} \cdot 2 \mathrm{~h}$ for $\mathrm{CO}$ production [20]. The high catalytic performance of $\operatorname{Re}(b t p)$ may be due to a high molar absorption coefficient $\left(7430 \mathrm{M}^{-1} \mathrm{~cm}^{-1}\right)$. However, for $\operatorname{Re}(\mathrm{bpy}-\mathrm{CN})$, which cannot 
reduce $\mathrm{CO}_{2}$ to $\mathrm{CO}$, the MLCT transition band had a long-wavelength shift due to the electron-withdrawing effect of the $\mathrm{CN}$ group. Photocatalytic inactivity under 365-nm light irradiation is probably due to a decrease in the percentage of excited species.

For future study, there is significant value in choosing an $\mathrm{R}$ of a low $\mathrm{C} 1 \mathrm{~s}$ group shift and examining the irradiation-wavelength dependence on $\mathrm{CO}$ production for detailed understanding and enhancement of $\mathrm{CO}_{2}$-reduction efficiency.

\section{Conclusion}

The substituent group $\mathrm{R}$ in the $\mathrm{Re}(\mathrm{bpy}-\mathrm{R})$ significantly affects both the degradation rate constant of $\operatorname{Re}(b p y-R)$ and $\mathrm{CO}$ production ability under $365-\mathrm{nm}$ light irradiation. To prevent degradation of $\operatorname{Re}($ bpy-R), the Rs of the low $\mathrm{C} 1 \mathrm{~s}$ group shift $\left(\Delta E_{g r}\right)$ may be potential candidates. There is also a correlation between the ability of $\mathrm{Re}(\mathrm{bpy}-\mathrm{R})$ to produce $\mathrm{CO}$ and molar absorption coefficients of each $\operatorname{Re}($ bpy-R) at the irradiation wavelength. Re complexes with higher molar absorption coefficient exhibit higher $\mathrm{CO}$ production ability. The novel $\mathrm{Re}(\mathrm{bpy}-\mathrm{COOH})$ produced $\mathrm{CO}$ at a rate of 6.59 $\mathrm{mol} / \mathrm{cat}-\mathrm{mol} \cdot 2 \mathrm{~h}$, which is five times higher than that of $\mathrm{Re}($ bpy-H) because of its high molar absorption coefficients at $365 \mathrm{~nm}$.

\section{References}

[1] K. Tanaka, "Carbon dioxide fixation catalyzed by metal complexes,” Adv. Inorg. Chem., 1995, 43, pp. 409-435.

[2] G. Calzaferri, K. Hadener, J. Li, "Photoreduction and electroreduction of carbon dioxide by a novel rhenium(I) p-phenyl-terpyridine carbonyl complex," J. Photochem. Photobiol. A: Chem., 1992, 64, pp. 259-262.

[3] J. Hawecker, Jean M. Lehn, R. Ziessel, "Photochemical and electrochemical reduction of carbon dioxide to carbon monoxide mediated by (2,2'-Bipyridine)tricarbonylchlororhenium(I) and related complexes as homogeneous catalysts," Helv. Chim. Acta, 1986, 69, pp. 1990-2012.

[4] H. Hori, O. Ishitani, K. Koike, K. Takeuchi, T. Ibusuki, "Electrospray mass spectrometric detection of unstable rhenium complexes as reaction intermediates of photochemical $\mathrm{CO}_{2}$-fixation," Anal. Sci., 1996, 12, pp. 587-590.

[5] H. Hori, Frank P. A. Johnson, K. Koike, O. Ishitani, T. Ibusuki, "Efficient photocatalytic $\mathrm{CO}_{2}$ reduction using $[\operatorname{Re}(\mathrm{bpy})$ $\left.(\mathrm{CO})_{3}\left\{\mathrm{P}(\mathrm{OEt})_{3}\right\}\right]^{+}$," J. Photochem. Photobiol. A: Chem., 1996, 96, pp. $171-174$.

[6] H. Hori, J. Ishihara, K. Koike, K. Takeuchi, T. Ibusuki, O. Ishitani, "Photocatalytic reduction of carbon dioxide using $\left[\text { fac-Re(bpy) }(\mathrm{CO})_{3}(4-\mathrm{Xpy})\right]^{+}$(Xpy = pyridine derivatives)," J.Photochem. Photobiol. A: Chem., 1999, 120, pp. 119-124.

[7] H. Takeda, K. Koike, H. Inoue, O. Ishitani, "Development of an efficient photocatalytic system for $\mathrm{CO}_{2}$ reduction using rhenium(I) complexes based on mechanistic studies," J. Am.
Chem. Soc., 2008, 130, pp. 2023-2031.

[8] K. Youki, N. Yu, M. Dai, S. Tetsuya, T. Shinsuke, T. Hiroshi, I. Haruo, "Direct detection of key reaction intermediates in photochemical $\mathrm{CO}_{2}$ reduction sensitized by a rhenium bipyridine complex," J. Am. Chem. Sci., 2014, 136, pp. 6021-6030

[9] J. Hawecker, Jean M. Lehn, R. Ziessel, "Efficient photochemical reduction of $\mathrm{CO}_{2}$ to $\mathrm{CO}$ by visible light irradiation of systems containing $\operatorname{Re}($ bipy $)(\mathrm{CO})_{3} \mathrm{X}$ or $\mathrm{Ru}(\text { bipy })_{3}{ }^{2+}-\mathrm{Co}^{2+}$ combinations as homogeneous catalysts," J. Chem. Soc. Chem. Commun. 1983, 9, pp. 536-538.

[10] J. Hawecker, Jean M. Lehn, R. Ziessel, "Photochemical and electrochemical reduction of carbon dioxide to carbon monoxide mediated by (2,2'-Bipyridine)tricarbonylchlororhenium(I) and related complexes as homogeneous catalysts," Helv. Chim. Acta., 1986, 69, pp. 1990-2012.

[11] O. Ishitani, Michael W. George, T. Ibusuki, Frank P. A. Johnson, K. Koike, K. Nozaki, C. Pac, James J. Turner, Jeremy R. Westwell, "Photophysical behavior of a new $\mathrm{CO}_{2}$ reduction catalyst, $\operatorname{Re}(\mathrm{CO})_{2}(\mathrm{bpy})\left\{\mathrm{P}(\mathrm{OEt})_{3}\right\}^{2+}$," Inorg. Chem., 1994, 33(21), pp. 4712-4717.

[12] P. Kurz, B. Probst, B. Spingler, R. Albertp, "Ligand variation in $\left[\operatorname{ReX}(\right.$ diimine $\left.)(\mathrm{CO})_{3}\right]$ complexes: Effects on photocatalytic $\mathrm{CO}_{2}$ reduction,” Eur. J. Inorg. Chem. 2006, pp. 2966-2974.

[13] J. V. Casper, T. J. Meyer, "Application of the energy gap law to nonradiative, excited-state decay,” J. Phys. Chem., 1983, 87, pp. 952-957

[14] H. Hori, Frank P. A. Johnson, K. Koike, K. Takeuchi, T. Ibusuki, O. Ishitani, "Photochemistry of $\left[\operatorname{Re}(\text { bipy })(\mathrm{CO})_{3}\left(\mathrm{PPh}_{3}\right)\right]^{+}($bipy $=$ 2,2'-bipyridine) in thepresence of triethanolamine associated with photoreductive fixation of carbon dioxide: participation of a chain reaction mechanism," J. Chem. Soc. Dalton Trans., 1997, 6, pp. 1019-1024.

[15] K. Koike, H. Hori, M. Ishizuka, J. R. Westwell, K. Takeuchi, T. Ibusuki, K. Enjouji, H. Konno, K. Sakamoto, O. Ishitani, "Key Process of the Photocatalytic Reduction of $\mathrm{CO}_{2}$ Using $\left[\operatorname{Re}\left(4,4^{6}-\mathrm{X}_{2} \text {-bipyridine }\right)(\mathrm{CO})_{3} \mathrm{PR}_{3}\right]^{+}\left(\mathrm{X}=\mathrm{CH}_{3}, \mathrm{H}, \mathrm{CF}_{3} ; \mathrm{PR}_{3}=\right.$ Phosphorus Ligands): Dark Reaction of the One-Electron-Reduced Complexes with $\mathrm{CO}_{2}$," organometallics, 1997, 16, pp. 5724-2729.

[16] K. Koike, N. Okoshi, H. Hori, K. Takeuchi, O. Ishitani, H. Tsubaki, Ian P. Clark, Michael W. George, Frank P. A. Johnson and James J. Turner., "Mechanism of the photochemical ligand substitution reactions of fac-[Re(bpy) $\left.(\mathrm{CO})_{3}\left(\mathrm{PR}_{3}\right)\right]^{+}$complexes and the properties of their triplet ligand-field excited states," J. Am. Chem. Sci., 2002, 124, pp. 11448-11455.

[17] H. Hori, Y. Takano, K. Koike, Y. Sasaki, "Efficient rhenium-catalyzed photochemical carbon dioxide reduction under high pressure," Inorg. Chem. Commun., 2003, 6, pp. 300-303.

[18] H. Takeda, O. Ishitani, "Development of efficient photocatalytic systems for $\mathrm{CO}_{2}$ reduction using mononuclear and multinuclear metal complexes based on mechanistic studies," Coord. Chem. Rev., 2010, 254, pp. 346-354.

[19] K. Kalyanasundaram, "Luminescence and redox reactions of the metal-to-ligand charge-transfer excited state of tricarbonylchloro-(polypyridyl)rhenium(I) complexes," J. Chem. Soc., Farady Trans. 2, 1986, 82, pp. 2401-2415. 
[20] Y. Ono, M. Tsuda, Yasuko Y. Maruo, J. Nakamura, "Kinetic study on $\mathrm{CO}_{2}$ photoreduction by Re complexes," Journal of Physics: Conference Series, 2012, 379, 012037.
[21] U. Geliud, P. F. Heden, J. Hedman, B. J. Lindberg, B. Manne, R. Nordberg, C. Nordling, K. Siegbahn, "Molecular spectroscopy by means of ESCA. III. carbon compounds," Physica Scripta, 1970, 2, pp. 70-80. 